\title{
Urban Riverfront Management
}

\author{
Dr. Swati Gole \\ (The author is retired as Reader, Department of Geography, S. P. College, Pune; \\ Founder Member of The Ecological Society, Presently Chairman of The Ecological Society)
}

\begin{abstract}
The plight of the rivers in India is pathetic, especially in the cities. Rivers flowing through the cities are polluted and filthy. They have become dumping grounds for waste. Therefore the health of the citizens is at risk.

Rivers are modified to a great extent by constructing dams, channelization, changes in the flow etc. This results in loss of their ecosystem functioning and natural services to man. The services given by the river include fresh water source, fishing, washing, swimming, sand as a raw material for construction, and many more. The esthetic use and relaxation on the river banks is an intangible service but important to the common man. All these services given by river are free of cost.

Present situation demands immediate attention to improve conditions of rivers. The solution is restoring the natural river system and re-developing river fronts sites based on ecological considerations. This involves stream channels, stream buffers and banks restoration. The restored river system contributes to a healthier environment and improves conditions for stream related human activities.

Typical plans for redevelopment of a river front are integrated and mixed-use, including public amenities such as parks, trails, cultural attractions like open theatre, wildlife watch-towers, preservation of historic structures like ghats and temples, and commercial establishments. However, the health of the river itself will not be restored if the following factors are ignored: alternative solutions for sewage, improvement in water quality, restoration of vegetation and habitats within the river and along its banks. In the redevelopment, access to river bank for common man is also an important element.

Such successful examples are so far seen in American and European cities. It is now high time to have holistic environmental planning in India.

Keywords : environmentally sensitive planning and design, mix-use development, access to river for common man, revitalization of river system, ecological services given by river
\end{abstract}

\section{Introduction}

Human society benefits from the services provided by the river. It is difficult to get these services if the river system is disrupted. Many a time, an urban riverfront is substantially modified due to human intervention. However, it is possible to revive the function of such rivers, if the riverfront is subjected to holistic and ecological management.

Human intervention causes river modification in several ways, such as channelization of flow, clearing of riparian vegetation and construction on the bank.
These interventions become barriers for the river system to function as a biotic system, adapted to the physical elements in that landscape. The smooth functioning of the riverine ecosystem is also important for the biodiversity, which is a positive feedback for the ecosystem to function normally.

It is quite important to understand the river ecosystem in general and its relationship with the physical, geomorphic, geographic and climatic aspects as much as the biota it supports, before we jump to the question of how we manage urban riverfronts in the best possible way. The background will help 
substantially, when we discuss strategies for urban riverfront management and its impacts upstream and downstream of the river.

\section{Background}

The most ubiquitous physical features over the land surface are streams and rivers which are a major source of water for terrestrial living beings including humans. The Indian Territory is endowed with more than $29,000 \mathrm{~km}$ of riverine resources (MPCB, 2011). In addition, river basins are closely associated with other elements such as mountains, hills, upland plateaus, floodplains and deltas among others. The streams/ rivers have an elongated/longitudinal continuum which can be called 'corridor'. Riverine corridors are of great economic, social, cultural and environmental value.

The watershed structure of rivers is composed of a network of streams and tributaries that feed the main river. The typical physical set-up of a riverine system consists of a source region in the hills or mountains, middle region of floodplains and mouth region characterized by deltas and estuaries. The river system evolves through long geological time to drain rain water. The physical geomorphic processes operating in the watershed are erosion, sediment transport and its deposition. The scale of these processes depends on the climatic regime and changes in the climate through geologic time. The scale and character of the physical features created by rivers differs from region to region depending on the type of climate and geology of that region. The combination of river processes along the river channel and geomorphic processes beyond the channel banks result in the hill-valley landscape commonly observed around us.

\section{Importance of River Systems}

However rivers are not just physical structures to drain rain water. As most of the rivers are flowing for past thousands of years, characteristic biological communities have evolved in the river water and in their vicinity. The biological communities conform to the physical conditions. The rivers are complex ecosystems. The relation of physical processes and the biotic community has been lucidly described by Prakash Gole (Gole, 2007) in the excerpt below:

'Life of a stream is characterized by flow and flood. The corresponding physical processes that get established due to a regime of flow and flood are: erosion of the surroundings, sediment transport and sediment deposition. The mixing of organic matter and minerals enriches the flow with nutrients on which many biological communities thrive. As the flow encounters physical barriers such as rapids and riffles, dikes and depressions the velocity of flow and sediment transport and deposition changes giving rise to different habitats in-stream and in the riparian zone with its characteristic vegetation. These habitats give food and shelter to a variety of producers into (plants), consumers (aquatic animals) and decomposers which utilize and recycle nutrients, imparting the flowing water a self-cleansing ability. In the head waters of the stream the channels is a receiver of nutrients and a breeding and nursery ground of fish and aquatic animals, while in the lower reaches, the stream channel is the donor of nutrients and the flood plain is their receiver. It is in the flood plain and the delta region that the major biological and wildlife value is concentrated, the stream therefore, comes to develop an organic relationship with land that it traverses.'

\section{Functioning of River Ecosystem}

The rivers evolve in response to surrounding ecosystems. Changes within a surrounding ecosystem will change the physical, chemical and biological processes occurring within a stream corridor. For example change of land use in the watershed such as increase in land under agriculture and pasture by cutting forest may lead to more erosion, sediment load and sediment deposition. It will create changes in the stream bed habitats and therefore changes in biological community. A river system normally functions within natural ranges of flow, sediment load, sediment transport, flood variations and other variables and has its 'dynamic equilibrium'. When changes in these variables go beyond their natural ranges, dynamic equilibrium may be lost. The changed character of the river may not fulfill social needs such as sufficiency of water resources.

Water, materials, energy and organisms meet and interact within a river over space and time. The influence of flow extends beyond river channel especially during floods. It extends into a riparian zone which is a space between slope processes and channel. The river channel and the riparian zone together provide critical functions essential for maintaining life in the river. The important functions are nutrient cycling, absorbing and gradually releasing flood waters, maintaining fish and wildlife habitats, recharging ground water so that aquifers release water in the channel during dry season. However biological functioning changes when there are significant changes in the physical processes. 
These changes may be natural or man-made. Many a time biological communities are unable to adjust with extreme physical disturbances. Therefore, it becomes difficult for the river ecosystem to function in equilibrium. Now let us see how natural and manmade disturbances affect the river ecosystem.

Besides physical functions there are biological functions. The riparian zone presents a series of aquatic and terrestrial vegetation bands or eco tones, through which matter and water exchange takes place. Energy is naturally dissipated as a variety of vegetation grows in the riparian zone. It adds vegetation debris to the flow providing food for aquatic organisms. The biotic component of the river filters contaminants in the flow. Figure 1 illustrates efficient interaction between aquatic and terrestrial ecosystems that enhances the self-cleansing ability of the river.

\section{Disturbances to River Systems}

\subsection{Natural Disturbances}

Disturbances in the river flow bring about changes in the river ecosystem. The disturbances can be natural or man-made. Natural disturbances include earthquakes, volcanic eruption, landslides of a major scale, forest fires, and spread of diseases in the forest. However the most common disturbances affecting the river flow are climatic events. The quantity (intensity), timing, and distribution of precipitation often cause major changes in runoff and the sediment load it carries.

The Indian monsoon climate is erratic. The nature of river flows studied by a group of geomorphologists describes it as follows: "High magnitude of floods during the monsoon season is considered to be India's recurring and leading natural disaster. Such large floods are extremely important events, not only in terms of human impact, but also from the standpoint of geomorphic effectiveness and geomorphic work. The flooding in such large rivers profoundly challenges flood-hazard management, because of limited instrumental records and large spaciotemporal variations. It is therefore imperative that the design engineering community in India incorporates the geomorphic, sedimentologic [sic] and botanic

Figure 1

Role of Riparian Vegetation in Stream Ecosystems

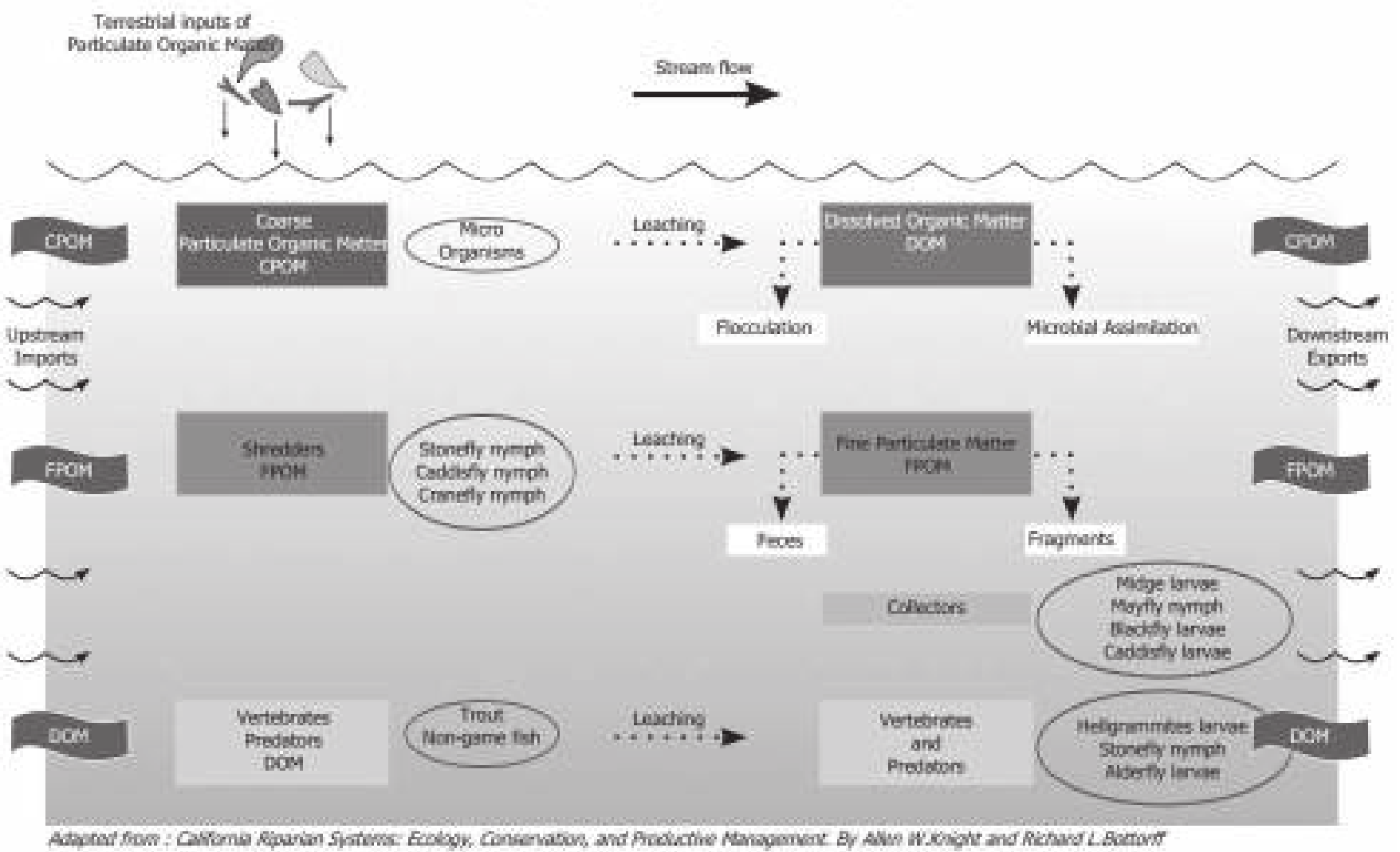


information in the planning and design of water resource development project." (Kale, 1994)

The erratic climatic factors also affect patterns of soil and vegetation in the landscape.

Natural climatic events such as storms, floods, temperature extremes, cloud bursts, droughts etc. are relatively regular events, especially in monsoon type of climate. Thus the natural events disturb structure and functions in the stream corridor. In such a situation certain species of plants have adapted their life cycles to the occurrence of destructive high energy disturbances such as alternating floods and droughts. An example is the tropical willow (Salix tetrassperma) which grows in the riparian zone of the rivers in Western Ghats, Maharashtra enduring the standing water of floods. Though there is significant distraction of the river ecosystem, channel and riparian biotic features are resilient to these natural events. They possess the quality of being in the dynamic equilibrium as a biotic community.

In modern times, man-made interventions to the riverine ecosystems are overpowering and are clearly seen as seriously interfering in the natural functioning of these rivers. This means there is a need for active management, which would not be required if maninduced disturbances were minimized in the first place. An overview of these disturbances and corresponding effects is in order before we come to the specific subject of Urban Riverfront Management.

\subsection{Man-made Disturbances}

Today's man-made disturbances have a very large scale. Man has manipulated the river systems for a wide variety of purposes. Modern human society is banking upon water resources for economic and industrial development. The water demand for industry, commercial agriculture and domestic use in big cities has increased tremendously. This has resulted in building of dams, and creation of big reservoirs to provide water through canals for these purposes. Almost all the rivers are now altered by man. The words of HBN Hynes(1998) are very relevant: "Human activities have profoundly affected rivers and streams in all parts of the world, to such an extent that it is now extremely difficult to find any stream which has not been in some way altered and probably quite impossible to find any such river". The modern system of water distribution not only contributes to changes in dynamic equilibrium of rivers but has completely devastated the natural drainage network of rivers.

Let us see how the interventions of construction of dams and changes in the land-use in the catchment area of the rivers affect river ecosystem. The changes are sequential and have a multiplier effect. Cumulative effects of these activities result in changes in the structure and functioning of the river ecosystem. The effects include changes in the flow regime, loss of habitat for fish and other aquatic flora and fauna, degradation of water quality, and decreased aesthetic value. Rivers no more carry potable water. The spread of exotic species of aquatic plants have hampered functioning of the river ecosystem. The usual sequence of changes is shown in Figure 2.

\subsubsection{Effects of dams, channelization and flow diversion on river channel geomorphology}

A major change takes place in river flow and discharge once a dam is built across the river. The river water is stored behind the wall. The river flow is then completely controlled by the new water supply and irrigation system. The river flows become irregular, sometimes very low discharges, or even dry

Figure 2

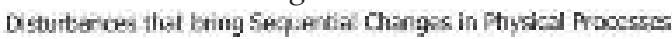

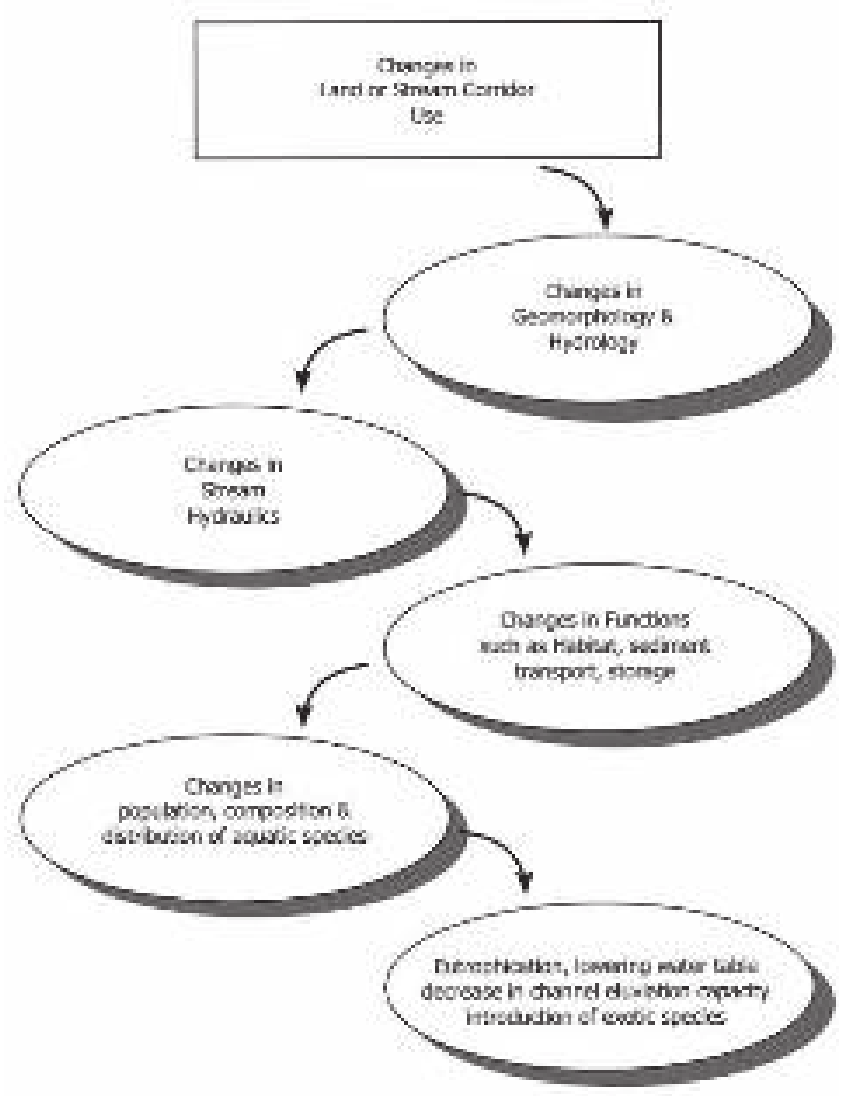


channel conditions. The water released in the river changes according to the demand for water by agriculture, industry and cities. This erratic nature of river flow affects hydrology and hydraulics of the river. The rainfall-runoff relation and channel's adjustment to these natural events is lost. Thus the velocity of the river flow, the character of the sediment that it carries changes significantly. The sediments coming from the upper catchment area are now deposited in the reservoir created by dam. Thus the river flow below the dam contains less sediment.

The current literature provides abundance of figures concerning the percentage of fine sediment which becomes trapped within the reservoir. Figures stated are commonly over 95 percent and have reported to be as high as 99 percent. References below from a literature survey are discussed ahead (Childs, 2010)(Leopold and Wolman, 1994; Butting and Shaw, 1973). "While flow released from the dam which has been termed as 'clear water' (Park, 1997; Kondolf, 1997; Brierley and Fryers, 2005) has excess energy due to transporting less sediment than it is capable of. Thus the river gains sediment by eroding channel bed and bank." (Petts, 1984; Annandale, 1987; Rosgen, 1996; Kondolf, 1997). All the geomorphic and hydrological studies show that the balance between erosion and deposition is lost because of hydrological changes caused by dam. This results in loss of valuable habitats such as sand bars, gravel beds and riffle and pool. The stream channel becomes incised. The stream incision may lead to lowering of local water table. The channelization and diversion of water also affect channel morphology. The lack of flood events can result in channel aggradation, the narrowing and infilling of secondary channels.

\subsubsection{Effects of geomorphic changes in the river channel on biotic community}

The rivers and streams are a continuum. It is a passage which joins distant areas. Therefore it acts like a highway for movement of flora and fauna. In case of plants seed dispersal takes place along the river corridor, and many aquatic organisms, especially fish, migrate upstream for spawning. The construction of dam obstructs the movement of resident and migratory fauna. This in turn affects the food chain associated with stream functions. Alteration of water quality affects biotic community in the river. Constant temperatures in the reservoir may not be suitable for species dependent on temperature variation for reproduction and maturation. Water released from the reservoir into the stream has low dissolved oxygen. It is also relatively cooler, due to which native species of fish may not adapt. Sediments coming from the higher parts of the watershed settle in the reservoir, however attached to this suspended sediment is organic material which provides vital nutrients for downstream food web. Thus the downstream food web is deficient in vital nutrient supply. (Refer to Figure No. 1) Sequential changes in channel bed habitat were observed after major forest fire by Barry Hecht ( 1982). According to his observations, massive fill of sediment temporarily buries most of the limited habitats with finer material, largely sand. This hampered spawning activity of fish (Hecht, 1982). The effects of channelization and diversion of water are significant. The channelization increases stream velocity causing stream bed erosion. It reduces habitat diversity. The riffle-pool complexes ${ }^{1}$ are needed at different times in the life cycle of certain aquatic organisms. These riffle-pool complexes are destroyed by channelization. The process of channelization removes obstacle if any in the channel. The large woody debris which supports aquatic macro invertebrates is removed.

In September 1981, California State Universities conducted conference on "California Riparian System, Ecology, Conservation, and Productive Management". The research papers covered various aspects of the riparian system. The paper "The importance of Riparian systems to amphibians and reptiles" was presented by J. M. Brode and Burry (1981) in this conference. Paper elaborates activities which affect riparian system adversely have their greatest effects on amphibians and reptiles. According to Knight(1981) amphibians and reptiles form a structural diversity of riparian system.

\subsubsection{Effects of changes in land-use}

Commercial agriculture is replacing traditional agriculture with the availability of canal irrigation. Change in the type of crop and greater area under agriculture results in greater soil erosion. This type of agriculture results in chemically defined disturbances to the river ecosystem. Pesticides and fertilizers used in agriculture leach out in the river water with surface

1. Pools are formed in a meandering stream on the outside of the bend due to scouring of the bed by higher velocity flow and deposition (riffle) is formed on the inner side of the bend 
runoff. Agricultural chemicals attached to sediments increase soil salinity.

Another significant change in land use is urbanization. Cities are growing at a rapid pace. As far as rivers are concerned, cities change rivers through addition of sewage water to the adjacent river in very large quantities. The fresh water component in such rivers is totally altered. River water utilization for fishing, bathing, washing, etc. is not possible. In many cases rivers become dumping areas. Municipal waste contaminates river water. Activities such as mining add acids and heavy metals to the river course. All the above mentioned activities have potential to disturb natural chemical cycles in the stream and thus degrade water quality. Widespread logging operations and road building severely alter soil moisture, soil nutrients, soil temperature, and subsoil water movement that are critical for persistence of the biotic community.

The scale of disturbances presently is very high. It results in irreparable destruction of the river ecosystems. The natural riverine ecosystem provide resources and services to man. Resources include water, fisheries, aquatic plants etc. and services include recharging ground water, distribution of soil in the landscape, amelioration of local climate, navigation and aesthetics, etc. All these attributes are valuable and make the river ecosystem selfsustaining. The low cost of maintenance and availability of the resources to all sections of the society is the beauty of this natural system.

The present situation of the rivers in India appears very pathetic. Government of India had to set up a pollution abatement program for rivers in India. As stated below in WHO water sanitation report: "It started in 1985 with Ganga Action Plan (GAP) and generally extended to other polluted rivers through National River Conservation Plan (NRCP). The current programs covered under NRCP include works in 172 towns along polluted stretches of various rivers spread over 20 states. The UNEP (R Helmer \& I Hespunhol, 1977) guide to the use of water quality management principles document says, "In the recent past, due to rapid progress in communications and commerce along the river Ganga, the river is no longer only a source of water but is also channel, receiving and transporting urban wastes away from the towns." This clearly calls for the rethinking of river management. However these programs are limited to river water pollution abatement. Revival of natural river ecosystem receives scant to no attention. Restoring river ecosystems contributes to a much greater extent to a healthier environment and improves conditions for ecosystem as well as human society. While the main service of the river ecosystem is providing clean water, it also supports activities such as fishing, boating and swimming. Other possibilities of creating multiple-use facilities such as parks, trails, cultural attractions like historic 'Ghats' built along the river increase river value in both aesthetic and commercial sense. Historical identity gives character to the river corridor. For example the town of Wai along the river Krishna is identified by a series of beautiful Ghats and temples, and the famous Krishna river festival is unique in its kind.

As we have seen the modern water distribution system of dams and canals and other man made disturbances have disrupted the natural ecosystem of rivers from source regions to the river mouth. Thus rivers are no more functioning as an ecosystem. As a result we are losing their natural value and also diminishing their economic function. For the revival of rivers comprehensive policy changes at the national level are urgently needed. However the scope of the present article being limited to ecologically sound riverfront management, let us now assess some of the ways in which urban river fronts could yet be managed to improve its health for urban dwellers and river organisms and ecosystem.

The new concept of improving urban riverfront areas is participation in planning and development by various stakeholders, government administrators, NGOs, citizens at large, and industry and commerce. The integration of natural values as well as facilitating commercial activity and providing amenities to citizens is essential. There are many examples of such kind of management in USA, European countries and even Asian countries. Malaysia is now focusing on mixed-use development and recreation for riverfront management. Let us see and review the early effort of ecologically sound riverfront planning of Mula-Mutha river of Pune city by The Ecological Society.

\section{Case Study of Conceptual design for Mula- Mutha Riverfront management}

In 1983 the concept of ecological planning was in infancy even abroad and in India difficult to accept for citizens and government authorities. The early effort by the Ecological Society to develop an ecodevelopment plan for riverfronts of Pune city was thus highly unique. Documented as "The Survey of the Rivers in Pune City Based on Ecological Factors, in order to prepare an Eco-development Plan to Improve the Riverfronts of Pune" (Ecological Society, 1983), 
this eco-development plan takes into account physical characteristics of the Mula-Mutha channel and its basin, the water quality, aquatic and riparian flora and fauna. The relation between the flora, fauna and the habitat quality was examined to understand ecology. The survey included observations about actual use of river by the citizens. The ecological observations were used as indices while suggesting a management and development plan.

\subsection{Highlights of the 1983 Survey}

\section{Physical Character}

The detailed survey describes various stretches of the river between Vitthalwadi and Bund garden. The habitat diversity was identified.

\section{Water Quality}

The water samples were analyzed. The results of the analyzed water samples showed very high bacteriological pollution : at Garaware bridge $2.5 \times 10^{6}$ per $100 \mathrm{ml}$, while below Shivaji Bridge and Bund garden area $3.5 \times 10^{6}$. This indicated that the water flow of Mula-Mutha was mostly sewer water. Water was not of the quality of washing clothes and bathing.

\section{Flora}

The vegetation survey was carried out according to habitats. Aquatic habitats like partly submerged, marshy places, plants growing along the drains and effluents, plants from dry places, plants growing in rock crevices, and bank vegetation were surveyed. The count came to 156 species. This is a significant reduction in species number compared to Dr. V.D. Vartak's survey of 1954-55, which recorded 400 species. Presence of invasive species like 'Eichornia', popularly known as water hyacinth, was not recorded in the 1954-55 survey. The 1983 survey indicates higher content of fecal matter and deterioration of water quality.

\section{Fauna}

The faunal survey was done in great detail. Ranging from small forms of insects like water bugs, mollusks, beetles, etc. to various types of fish and birds. The habitat quality was assessed by observing biodiversity and ecology. To assess the water quality from wildlife perspective and general status of the river ecosystem, bird distribution of certain indicator species were used as an index. The distribution of egrets, stilts, grebes and gull-billed terns showed that they were numerous at places where streams loaded with fecal matter flow into the river.

\section{Human Activities}

Human activities were observed from two perspectives: a) activities of citizens which contribute to maintenance of river ecosystem and $b$ ) destruction of the river environment. The services provided by the river to citizens were observed. These observations show:

- River no more provides drinking water.

- Citizens are washing clothes, cattle, vehicles in the polluted water.

- River is no longer providing remunerative fishing.

- Residential buildings have encroached upon open spaces on the river bank. No room is left for structural design of the river bank.

- Uncontrolled activities in the proposed green zone. Based on these observations an ecologically sound river front development plan was proposed. The plan was developed taking into account feasibility of the suggested action.

Plan highlights

1. Restoration of habitats along both the channel bed and bank were suggested. The details of the type of action and sites were given. For example, preservation of rocky and marshy places near Vittalwadi or deepening of channel at the confluence of Mula and Mutha rivers.

2. For cleaning of sewage water a new concept of detention basins was suggested. In these basins sediment would settle and water will be partly free of fecal matter. This is a low cost solution. The detention basins can have multiple uses. They can store flood water and then release during dry summer season. They act as wetlands with all its associated advantages. The wetland will increase habitat diversity of the river ecosystem and environmental value. The purified water could also be used for municipal and private gardens along the river front.

3. How the use of the river by citizens is to be regulated with very little disturbance to the river system while still allowing citizens to benefit from the river was taken into account. The proper places for various activities such as clothes, cattle washing etc. were chosen.

4. Tree plantations on fallow private lands which form riparian zone of the river was suggested. Similarly, to develop parks and trails through the natural parks, taking over of private lands by municipal authorities was suggested. Some open 
spaces were suggested to have playgrounds which are essential as open space for playing is becoming scarce.

Thus, the riverfront plan included abatement of pollution at low cost, facilities to citizens, preservation of natural character, functioning of the river, and beautification of the river. However, this plan didn't include any commercial activity along the riverfront.

Several favorable circumstances existed in 1983 for the proposed ecologically sound river front plan.

a. The river channel was more or less naturally flowing and there were minimum interventions.

b. Within the river basin and over the bank many open spaces were available. At places even riparian vegetation existed. The settlements or commercial buildings were not touching the river basin.

c. The scale of sewage water in the river was relatively less as there was no development of new residential areas in the western part of the city. As the city is growing, proportion of sewage water coming in the river is increasing significantly.

The present situation is far more complex and worse.

a. There is pressure on the open spaces; most of the open spaces along the river are now built and high rise buildings are coming up. Thus there is no space left for riparian vegetation.

b. Within the river basin there are many changes. The naturally flowing river is channelized. Thus, it has lost its ecosystem value.

c. The space created along the channelized flow is utilized for commercial purposes like letting it out for circus since all other open spaces in the city have been lost to construction. Roads have been built on both the right and left of the river channel within the basin to avoid traffic congestion. Thus, the river corridor which used to bring in fresh air from the west is now distributing polluted air in the city.

d. Bank and riparian vegetation is completely lost.

With such a situation, to develop an eco-sensitive plan is a big challenge. However, the new concept of integrated management may be possible. There are very few open spaces along the river Mula-Mutha. The corridor of open space along the river, below the 'Bund Garden Bridge' exists. This place was proposed for the Mula-Mutha bird sanctuary. If revived, it will provide a facility for citizens to experience nature. Similarly small pockets of plantation in the riparian zone, with indigenous trees can be created at various places. E.g. near the Vittalwadi temple. A strong will on part of citizens, efforts by NGO's and active groups of citizens can bring about a dramatic shift in the situation. The thoughts of Sri Prakash Gole about urban design paradigm shift are appropriate to cite here. "Design needs to shift from a paradigm of transforming nature to one of transforming society by improving life quality and relationships between all living things and built environment" Gole, (2008).

\section{Challenges to plan Integrated Riverfront Management in India}

How is such a paradigm shift to be achieved? There are many difficulties: How to change political, administrative mind-set/ and view towards such planning? As the open spaces are very valuable to commercial interests in the urban areas, there is a conflict between commercial interests and the need for space for natural elements and processes as prescribed by ecologically sensitive planning. It is hard to bring together stakeholders, NGOs, administrators and funding agencies. It is challenging to make citizens aware of the pathetic situation of the rivers and reasons behind it. Even if citizens are made aware, it is difficult to translate their interest into action. Similar difficulties and challenges were faced by the developed nations and various models for improving river fronts in urban areas have been developed in these nations. Let us now review some of them.

\subsection{Models of Riverfront Development}

It may surprise readers today to learn that the condition of rivers in the USA was around the 1940s very similar to the conditions in India today. The following passage quoted from American Planning Association's planning advisory service report No. 518-519 says :

"In 1948, a water pollution law" was introduced in the USA that helped in executing basic treatment of raw sewage before dumping it into rivers. In the 1960s the environmental movement galvanized the masses. In 1972, landmark environmental legislation was passed by the US Congress; the Water Pollution Act and Clean Water Act. This Act created massive spending programs to construct wastewater treatment facilities and reduce the volumes of raw sewage flowing into the nation's waters. The EPA estimates that since the passage of the Clean Water Act more than $\$ 1$ trillion has been spent to upgrade and expand

\section{Federal Water Pollution Control Act of 1948}


wastewater treatment facilities (U.S. EPA 2001c). Industry and other municipal dischargers were required to clean up their effluent and obtain permits for the first time. These efforts have led to enormous improvements in water quality. Previously, industrial pollution, sewage, and decomposing algae fed by the waste had turned many urban rivers into stomach-turning cesspools. Few people were interested in standing near these rivers, much less dining or enjoying an open-air concert on their banks. The cleaner urban rivers that emerged by the 1980s were not just aesthetically appealing; they were healthier and thus able to sustain a wider diversity of fish, birds, and other wildlife. These improvements drew the public to the water's edge to walk, bike, boat, fish, and observe wildlife. As people returned to the river, they expressed a stronger interest in protecting and restoring natural areas and wildlife habitat" Otto, McCormik, \& Leccese, (2004).

The renewed attention to waterfronts in the 1970s coincided with a growing interest in historic preservation and with efforts to counteract suburban flight by reviving the urban core. These early urban riverfront initiatives thus sparked a redevelopment trend that accelerated in the late 1970s and boomed in the 1980s and 1990s. More recently a desire for more park space and greenways as well as growing appreciation for "green infrastructure" benefits has led further initiatives in riverfront redevelopment.

The early efforts to create example of riverfront development were from Baltimore, Boston and Toronto (Canada). These cities are often cited as early leaders in this trend. Baltimore's highly successful Inner Harbor Redevelopment is a model that has been studied and copied throughout the world (Otto, McCormik, \& Leccese, 2004).).

The concept of riverfront development include: A place that contributes to the quality of life in all of its aspects-economic, social and cultural. In riverfront development the following aspects are included, environmental, historic, cultural, recreational, working etc. However the main objective is to make degraded river ecosystems functional. The river bank space is mixed-use. The mixed-use includes mix of retail, housing, offices, restaurants, open space etc. It is a dynamic space containing various activities blended to complement each other.

The example of Guadalupe River is a typical one (Texas Government, 2014). The Guadalupe River has a long history of winter flooding that has repeatedly damaged adjacent homes and businesses, in San Jose, California. The flood protection, coupled with the community's desire for open space, resulted into Guadalupe River Park. This was developed by the city of San Jose in conjunction with a federal flood control project. It is a three mile long stretch of park along the river. The project provides recreational amenities to the local community, and an ecologically sound system of flood control and habitat restoration. While protecting the ecological integrity of the river, the system will have the capacity to divert significant amount of flood water to an existing floodplain. Extensive mitigation plantation of indigenous species is part of the project. An extensive system of recreational trails extends and links neighborhoods. Play grounds, picnic areas make the park a center of active urban life. Integrated into plazas along the trails are interpretation centers on history, ecology, and hydrology of the river to inform and educate the citizens that use the river trails for walking, bicycling, jogging and other recreational activities.

This is a good example of integration of mix-use planning. The concept of riverfront development is expanding all over the world. There are examples from Europe as well as Asia. The Vidin city in Bulgaria decided to improve riverfront of the Danube River. The conceptual design was first created in collaboration with the city of West Carrollton, Ohio State, USA. Under the Bulgarian Technical Program, the conceptual design provided a development strategy for next 5 to 10 years. The project adopted a systematic approach to solve problems. The team visited USA to see various waterfront parks which gave them a broad picture of Park development in USA (Development of a Conceptual Design for Vidin Riverfront Park; ICMA 2002).

Another example is from Malaysia. In Malaysia the trend of riverfront development is popular, and many cities have riverfront development. The riverfront development goals and guidelines are monitored by Malaysian Government and its effectiveness was studied by Tun Hussein Onn University students. According to the study, the implementation of the riverfront projects is driven more by investment needs than by community and environmental needs. Most of the developers were familiar with the guidelines for riverfront development concept proposed by the Malaysian Department of Drainage and Irrigation. The majority did not support the guidelines for many reasons including its ineffectiveness in controlling environmental problems. (Azlina Binti; Md Yasin).

All these examples show mixed results and hard efforts needed to complete the project. There is one example from India. Government of Gujarat has an experimental riverfront development project of Sabarmati. This project was initiated by Ahmedabad 
Municipal Corporation, to develop the Sabarmati riverfront in the city of Ahmedabad. The project is undertaken with the prime objective of environmental improvement and provision of housing for the poor who live in life threatening conditions along the river bed. It is being developed by Sabarmati Riverfront Department Corporation Ltd. (SRFDCL), funded by central Government of India, established in 1997. A seed capital of Rs. 10 million was given to SRFDCL. The main problem in the riverfront development was of hutments in the river channel. The rehabilitation was the main issue. The project has been planned as a self- financing project. The SRFDCL decided to utilize and sell the riverfront space to raise funds. 10 percent of the space was reserved for rehabilitation of slum dwellers, 21 percent for residential and commercial purposes and rest for promenades, like informal markets, gardens and to extend road network. One curious fact is that the floor space index (FSI) has been raised up to five and this may lead to higher density of built up area along the river front. To develop the riverfront SRFDCL had also uniformly narrowed the channel to 275 meters.

Looking at the project report it appears that the prime objective of environmental improvement has been sidelined. There is no mention of any ecological improvement, or habitat improvement, except development of gardens in the project report. Unless there is determination to restore river system, such riverfront projects would continue to focus only on the built environment. The examples of American, European and Asian riverfront development show a similar view, with some exceptions like the Guadalupe River Project. The river bank spaces are utilized mostly for mixed-use. The development of parks along the river is not a revival of the riparian system.

In order to overcome these problems, ecologically sound riverfront development principles must be strictly followed. In addition, to execute the riverfront development project formation of a systematic group is essential. It is now high time for the wave of ecologically-sensitive riverfront revitalization to come in India. One such effort which has recently been initiated is the revitalization of Mula-Mutha River in Pune called "Jeevit Nadi" (Living River). One hopes many more such groups sprout in other cities around India.

We attempt to state the basic principles of ecologically-sensitive riverfront development that we hope will prove helpful for such groups working in riverfront development at the design stage. These principles are taken from American Planning Advisory Service Report No. 518-519. (Otto, McCormik, \& Leccese, 2004).

These basic principles are developed with a view that planners can achieve much greater environmental as well as social and economic success if urban riverfronts are designed with ecological principles in mind.

The General Principles of Ecologically Sound Riverfront development include :

- Ecological goals and economic development goals are mutually beneficial

- Protect and restore natural river features and functions

- Regenerate the riverfront as a natural realm

- Compromises are necessary to achieve multiple objectives

- Make the process of planning and designing riverfronts broadly participatory and transparent

These principles are self-explanatory. To actually plan a design, the designing group has to take into account certain planning principles. The following planning principles should be integrated into master plans and implemented through zoning and building codes, engineering standards and site plan and design.

\section{The Planning Principles}

- Demonstrate characteristics of city's unique relationship to the river in the design

- Plan for a scale larger than the riverfront

- Minimize new floodplain development

- Explore if existing riverfront development can be moved to create more space for the river to function through use of buffer zones

- Provide the public access, connections and recreational uses

- Calibration of the river's environmental and cultural history and education

All the above principles are guidelines and provide methodology for planning the riverfront design. In addition riverfront planning must reconcile development and recreation with environmental designs and strategies. Every riverfront requires a unique combination of environmental strategies. The strategies must take into account the following characteristics of the specific river corridor :

The intensity of current development: Intensity of development can be classified according to percentage of hard surfaces like roads. Ultra urban $=80$ to 100 percent, urban $=40$ to 79 percent, suburban $=10$ to 39 percent. 
Infrastructure: Planners must be sure to identify all infrastructure features, like network of cables or drainage pipes. Planners must identify infrastructure such as network of roads, sewer pipes and electrical cables and incorporate them into riverfront plan.

Watershed Planning: The health and the vitality of a river cannot be improved without the comprehensive treatment of storm-water and other erosion and pollution sources across the watershed. This also calls for understanding the upstream situation and explore how one can tackle the catchment and command areas of any upstream dams existing at the time of planning.

Geometry and constraints of riverfront: Planning purpose and management should take into account community's views, planning solutions appropriate to unique conditions of the riverfront. River size and its geometry and river classification is also important.

\section{Getting Organized}

To start the process of planning, interested groups must get organized. The US Federal Interagency Stream Restoration Working Group has suggested certain strategies for effective organization, which can be paraphrased as follows :

- Setting geographical boundaries

- Forming an advisory group

- Establishing technical teams

- Identifying funding sources

- Establishing points of contact

- Facilitating involvement and information sharing among participants

- Documenting the process

The complex nature of stream corridor development and restoration requires that any such initiative be approached from an interdisciplinary perspective. Specialists from a variety of disciplines can provide important input for this effort. The following list of specialists could prove important:

$\begin{array}{ll}\text { Forrester } & \text { Soil Scientist } \\ \text { Botanist } & \text { Ecologist } \\ \text { Microbiologist } & \text { Landscape architect } \\ \text { Fish and Wildlife biologist } & \text { Engineer } \\ \text { Economist } & \text { Geomorphologist } \\ \text { Real estate experts } & \text { Legal consultant } \\ \text { Sociologist } & \text { Hydrologist }\end{array}$

\section{Conclusion}

The article hopes to provide necessary minimal background for policy makers who are interested in creating livable urban environment, where riverfronts are possibly the most important yet the most neglected areas. The paper also provides some cases where riverfront management has been attempted with mixed success.

To ensure that the future of our cities is far better than its recent past, there is an urgent need to improve both ecological and human health in urban areas. One way to realize this goal is to restore our river ecosystems at large and more specifically urban river fronts.

The author hopes that these management guidelines will provide a good starting point for the interested citizen or a policy-maker to lean towards the ecological restoration of urban river fronts for the benefit of the society.

\section{Bibliography}

1. Maharashtra Pollution Control Board. (2011). Assessment of Riverine Fisheries and Linking with Water Quality Restoration Programme. Versova, Mumbai : Central Institute of Fisheries Education

2. Prakash Gole (2007), Restoration of Nature, Ecological Society, Pune

3. Vishwas Kale, L. E. (1994), Geomorphic and Hydrologic aspects of monsoon floods on the Narmada \& Tapi rivers in Central India 1994 Geomorphology Journal Vol 10- 157-168

4. HBN Hynes (1998) FISRWG. Stream Corridor Restoration: Principles, Processes, and Practices. Federal Interagency Stream Restoration Working Group (FISRWG)(15 Federal agencies of the US Govt.)

5. Childs, 2010 (Leopold and Wolman, 1994; Butting and Shaw, 1973, Park, 1997; Kondolf, 1997; Brierley and Fryers, 2005, Petts, 1984; Annandale, 1987; Rosgen, 1996; Kondolf, 1997- (May 2010) Literature Survey, "Impact of Dams on River channel geomorphology", Department of Geography, University of Hull

6. Knight, A. W. (1984). The Importance of Riparian System to Amphibians and Reptiles, Importance of Riparian Vegetation to Stream Ecosystems. Proceedings of California Riparian Systems Conference UC Davis September 1981. University of California, Davis.

6. Barry Hecht (1982), Sequential Changes in Bed Habitat Conditions in the upper Carmel River, Following The Marble-Cone Fire of August 1977, Proceedings of California Riparian Systems Conference UC Davis September 1981. University 
of California, Davis.

7. Broad \& Burry, 1981, California Riparian System, Ecology, Conservation, and Productive Management" University of California Press

8. Helmer \& Hespunhol (1977), UNEP 1977, Pollution Control- A guide to the Use of Water Quality Management Principles

9. Prakash Gole (1983) The Survey of the Rivers in Pune City Based on Ecological Factors, in order to prepare an Eco-development Plan to Improve the Riverfronts of Pune, Ecological Society, Pune

10. V.D.Vartak (1958) "The Study of the flora of the Mutha river-bed near Poona", Poona Agricultural College Magazine, 49 : 121-132

11. Prakash Gole (2008), Understanding Reality Ecological Society, Pune

12. Betsy Otto, Kathleen Mc Cormik, and Michael
Leccese 2004, Ecological Riverfront Design. Restoring Rivers connecting Communities. 2004 American Planning Association Report no. 518519

13. Guadalupe-Blanco River Authority of Texas published by Texas State Historical Association

14. ICMA 2002, Development of a Conceptual Design for Vidin Riverfront Park

15. Azlina Binti Md Yasin, e.a. (n.d). The effectiveness of the riverfront development guidelines in Malaysia. Gold Coast, Australia

16. Retrieved from Wikipedia. org/wiki/Sabarmati Riverfront Development Project

17. Otto, McCormik, \& Leccese, 2004, Ecolcogical Riverfront Design, Planning Adivisory Service Report, 518-519. 